\title{
Career preferences of medical undergraduates of Sri Lanka; influence of exposure to specialties on career choice
}

\author{
Pinto, V. G. ${ }^{1}$, Galketiya,K.B. ${ }^{2}$, Jayasingheararchchi,D.K. ${ }^{3}$, Bandara, S. M. ${ }^{3}$, \\ Wijesinghe, D. L. ${ }^{3}$
}

\begin{abstract}
In Sri Lanka, the rapid growth in the health sector provides medical undergraduates a far wider range of disciplines for carrier advancement. A multitude of factors such as socio-cultural values, economics, and peer recognition influences the decision on the future of a medical graduate. We studied the influence of exposure to different specialties in the curriculum on carrier choices and the changes that occurred after a carrier guidance programme. The lack of any obvious changes in career preferences over three decades at the same institution suggests that the curriculum, despite changes during that period does not reflect the stated objectives of the Ministry of Health, confirming that the curriculum is not occupational or job orientated. The need for co-ordinated dialogue between medical schools, Ministry of Health and medical organizations such as the e.g. Sri Lanka Medical Association which provides an independent forum for such interactions is a necessity to meet the specialist requirements of this country.
\end{abstract}

Key words: Career choices, clinical exposure, medical undergraduate curriculum, medical education

\section{Background}

It is no doubt that the field of Medicine has evolved leaps and bounds over the past decade. This remarkable advancement in medicine opened up new gateways and opportunities for medical graduates who are in search of a field to practice as a career.

Deciding the field of future career is a complex personal decision influenced by different factors and one of the most crucial decisions any medical undergraduate has to make.

${ }^{1}$ Senior Lecturer, Department of Anaesthesiology, Faculty of Medicine, University of Peradeniya.

${ }^{2}$ Senior Lecturer, Department of Surgery, Faculty of Medicine, University of Peradeniya.

${ }^{3}$ Assisstant lecturer, Department of Anaesthesiology, Faculty of Medicine, University of Peradeniya.

Corresponding Author:

Dr. Vasanthi G Pinto Senior lecturer, Department of Anaesthesiology, Faculty of Medicine, University of Peradeniya

E-mail:vasantipinto@yahoo.com
It may be possible the majority of medical undergraduates are unaware of these newly established medical specialties and subspecialties. Thus a question was raised, whether they are more likely to carry out their higher studies in the fields that they are more exposed or known during their undergraduate period (Hauer et al., 2008). The Department of Health Services document in 2000 indicated the need for 846 specialists (consultants) when 541 were available. WHO/SLMA workshop in 2006 had indicated specialties where 2015 targets would be difficult to achieve and it is worth examining whether the undergraduate curriculum in some manner reflects the needs of the ministry of health (Howe and Lves, 2001).

A survey of career preferences was carried out in the same University of Peradeniya in 1984. (Karalliedde et al., 1986) This study was an expansion to determine any changes in career preferences and to obtain exposures to specialties in medical curriculum as a determinant of the career choice. It was evident that there was a void of study as in 1984 to report the recent status in Sri Lanka. 


\section{Objectives}

- To determine the career preferences of the third, fourth, final and immediate post-final medical undergraduates of University of Peradeniya and how it changes over the study year.

- To compare these career preferences with the clinical exposure of specialties.

- To evaluate whether the preferences change after getting exposed to the career guidance Programme.

\section{Methodology}

This descriptive cross sectional study was carried out among all consenting third, fourth, final medical undergraduates of Faculty of medicine University of Peradeniya. A pre tested, self-administered questionnaire was used as the method of data collection. This comprised of 15 questions, collecting information with regard to demographic data, field of interest, reasons for choosing the respective field of interest and the idea of overseas employment.

The career choices were analysed with the period of exposure to specialties for a given academic year of clinical exposure.

The same questionnaire was given to the post final undergraduates after a career guidance Programme. Results were again compared between before and after a comprehensive career guidance programme.

Data were analysed using SPSS16.0 package. Data were expressed as percentages, and Chi squared test was used as the statistical method at a 95\% confidence interval and $\mathrm{p}<0.05$ significance level.

\section{Results}

Results/Research data is summarized in the table 1, 2 and 3 , as well as in figure 1 .

Table 1: Demographic data of four batches.

\begin{tabular}{llllll}
\hline & Third year & Fourth Year & Final Year & $\begin{array}{l}\text { Immediate } \\
\text { Post-Final }\end{array}$ & Total \\
\hline Total Number & 140 & 110 & 191 & 127 & 568 \\
\hline Male & $69(49 \%)$ & $49(45 \%)$ & $81(42 \%)$ & $60(47 \%)$ & 259 \\
\hline Female & $71(51 \%)$ & $61(55 \%)$ & $110(58 \%)$ & $67(53 \%)$ & \\
\hline
\end{tabular}

More female students were observed in all four years.

Table 2: Willingness to pursue higher studies.

\begin{tabular}{lcccc}
\hline & Third year & Fourth Year & Final Year & $\begin{array}{c}\text { Immediate } \\
\text { Post-Final }\end{array}$ \\
\hline Total Number & 140 & 110 & 191 & 127 \\
\hline $\begin{array}{l}\text { Number preferred post } \\
\text { graduate studies }\end{array}$ & 101 & 85 & 138 & 104 \\
\hline $\begin{array}{l}\text { Percentage } \\
\text { Chi square } \mathrm{p}=0.18\end{array}$ & $72 \%$ & $77 \%$ & $72 \%$ & $82 \%$ \\
\hline
\end{tabular}




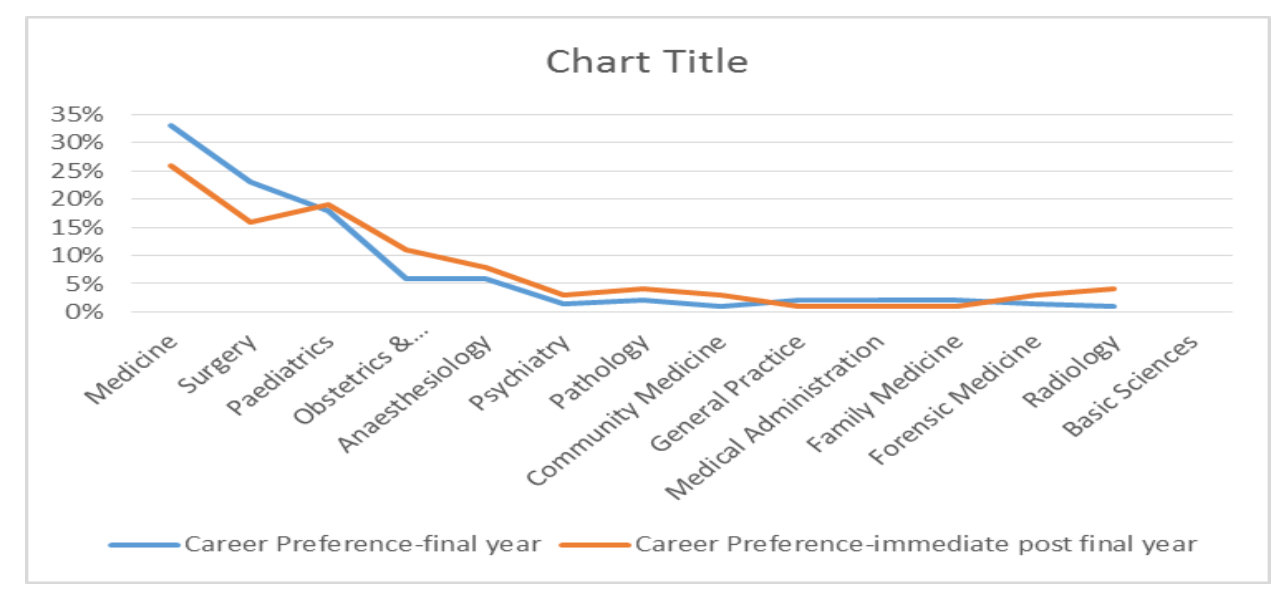

Figure 1: Comparison of career preferences before (final year undergraduates) and after the career guidance Programme (immediate post final year undergraduates)

\section{Discussion}

In Sri Lanka, the mere concept of being a medical 'doctor' had always been considered to be a luxury. Of them, those who specialize in a certain field are in the top of the hierarchical order. In a study that was carried out in 1984, it was noted that majority of students were attracted to the four 'established' specialties, namely medicine, surgery, obstetrics and gynaecology and paediatrics. Medicine ranked highest amongst these specialties (Hauer et al., 2008). The main attractions for these specialties may be the social prestige, financial benefits and direct contact with people. And the social stigma that an ideal doctor is a person coming from these specialties. The same trend was observed in our study population as well (Table 3).

Table 3: Career preferences of students of four batches compared with the weeks of clinical exposure

\begin{tabular}{|c|c|c|c|c|c|c|c|c|}
\hline \multirow[t]{2}{*}{$\begin{array}{l}1^{\text {st }} \text { Career } \\
\text { Preference }\end{array}$} & \multicolumn{2}{|l|}{ Third } & \multicolumn{2}{|c|}{ Fourth } & \multicolumn{2}{|l|}{ Final } & \multicolumn{2}{|c|}{$\begin{array}{l}\text { Post final }{ }^{* *} \text { (after } \\
\text { the clinical } \\
\text { guidance) }\end{array}$} \\
\hline & ${ }^{*}$ Wks & $\begin{array}{l}\text { Number } \\
\text { selected } \\
(\%)\end{array}$ & ${ }^{*}$ Wks & $\begin{array}{l}\text { Number } \\
\text { selected } \\
(\%)\end{array}$ & ${ }^{*}$ Wks & $\begin{array}{l}\text { Number } \\
\text { selected } \\
(\%)\end{array}$ & ${ }^{*}$ Wks & $\begin{array}{l}\text { Number } \\
\text { selected } \\
(\%)\end{array}$ \\
\hline $\begin{array}{l}\text { General } \\
\text { Medicine }\end{array}$ & 4 & $44(31 \%)$ & 28 & $35(31 \%)$ & 36 & $46(24 \%)$ & 36 & $31(24 \%)$ \\
\hline General Surgery & 4 & $27(19 \%)$ & 28 & $22(20 \%)$ & 36 & $32(17 \%)$ & 36 & $17(13 \%)$ \\
\hline Paediatrics & 8 & $7(5 \%)$ & 8 & $5(5 \%)$ & 16 & $25(13 \%)$ & 16 & $20(16 \%)$ \\
\hline Obs \&Gyn & 8 & $11(8 \%)$ & 8 & $4(4 \%)$ & 16 & $8(4 \%)$ & 16 & $12(9 \%)$ \\
\hline Anaesthesiology & - & $1(1 \%)$ & 4 & $4(4 \%)$ & 4 & $8(4 \%)$ & 4 & $8(6 \%)$ \\
\hline Psychiatry & - & $1(1 \%)$ & 4 & $10(9 \%)$ & 4 & $2(1 \%)$ & 4 & $3(2 \%)$ \\
\hline Pathology & 3 & - & 3 & - & 3 & $3(\%)$ & 3 & $4(3 \%)$ \\
\hline $\begin{array}{l}\text { Community } \\
\text { Medicine }\end{array}$ & 4 & - & 4 & $1(1 \%)$ & 4 & $1(1 \%)$ & 4 & $3(2 \%)$ \\
\hline General Practice & 1 & $1(1 \%)$ & 1 & - & 1 & $3(2 \%)$ & 1 & $1(1 \%)$ \\
\hline $\begin{array}{l}\text { Medical } \\
\text { Administration }\end{array}$ & - & - & - & $1(1 \%)$ & - & $3(2 \%)$ & - & $1(1 \%)$ \\
\hline Family Medicine & - & - & - & $1(1 \%)$ & - & $3(2 \%)$ & - & - \\
\hline $\begin{array}{l}\text { Forensic } \\
\text { Medicine }\end{array}$ & - & - & 4 & - & 4 & $2(1 \%)$ & 4 & - \\
\hline Radiology & - & $2(1 \%)$ & 2 & $1(1 \%)$ & 2 & $1(1 \%)$ & 2 & $4(3 \%)$ \\
\hline
\end{tabular}


Career preference may be related to the academic and clinical exposure (Mendis et al., 2006).

It was noted there was an improved percentage in the undergraduates wishing to pursue higher studies. It remained stable and not significantly changed during the advancement of undergraduate years of training which encouraging (Table2).

In an attempt to obtain the determinant in the career preferences in our study it was noted that of the third year students, $91 \%$ career choices were associated with 'major' specialties (i.e. medicine, surgery, gynaecology and obstetrics, paediatrics) which had the $75 \%$ of cumulative clinical exposure (Morrison and Murray, 1996) (Table 3) Although these students were immediately after the pre-clinical period (basic sciences), it was very noticeable that none selected basic sciences (e.g. anatomy) as their career preference. Whereas specialties such as anaesthesiology, psychiatry and radiology, were selected by third year undergraduates, even without proper clinical exposure to these subjects. Possibly due to introduction of these specialties in the preclinical teaching programme as an application to basic sciences.

Considering the choices of fourth and final year medical undergraduates, while maintaining the similar type of attention to 'major' specialties, they have shown an interest to new specialties such as community medicine, psychiatry, anaesthesiology and pathology (despite much less exposure time in the curriculum) owing to the fact that advanced clinical exposure may divert the student's interest to other fields or the students may have come to realize the importance of minor specialties.

Even though changing trends were shown over the years of academic exposure, percentage of students who selected some specialties as a career choice such as family medicine, general practice and medical administration did not change. Less clinical exposure deficient stimulation and awareness of these specialties during undergraduate training, less contact with patients, less financial reward and less job opportunities in Sri Lanka may have contributed to these low figures. In the literature these factors have shown some influence to decide on the career preference

Although the two final year groups had the same clinical exposure, responses following the career guidance Programme revealed a more diverse pattern (Figure1) as this may have provided an overview of facilities for higher education/training and job opportunities within the country for the specialties including to which they had less exposure during the undergraduate curriculum.

The changes in responses justify the importance of introduction of career guidance lectures probably at all stages of the medical curriculum, which would enable the students to make more realistic choices and provide a pragmatic approach to career choices from the expanding range of medical specialties and emerging job opportunities and facilities for post-graduate training in Sri Lanka.

Several documents from the WHO, SLMA and Ministry of Health at regular intervals have indicated the need for specialties such as family medicine or general practice that is accepted to form the backbone of a primary care and referral system in a country. Other concerns are the shortages of staff for basic sciences in medical schools that have nearly tripled since 1984 and that of pathologists- the latter two providing adequate exposure in the present curriculum. It is apparent from the minimal changes in career choices after three decades that the students appear to be uninformed or not provided with adequate information of changes and developments of the health care system in the country.

\section{Conclusion}

Career choices showed a positive relationship with the period of exposure to clinical specialties during the undergraduate curriculum education about the career choice and its availability influences this decision.

It may be necessity of the changing of time period of exposure in each subject laid as the curriculum which is often dull and tedious. But allocation of at least one to two hours (per semester) of career guidance, commencing from third year medical graduates will improve their higher education choices.

\section{Acknowledgement}

We are grateful to Prof. L.D. Karalliedda for his valuable guidance in preparing this manuscript and we are thankful to the Dean of the Faculty of Medicine University of Peradeniya, Prof. M.D.Lamawansa for his support. And the nonacademic staff of Department of Anaesthesiology for secretarial work. 


\section{References}

Hauer, K.E., Durning, S.J., Kernan, W.N., Fagan, M.J., Mintz, M., O'Sullivan, P.S., Battistone, M., DeFer, T., Elnicki, M., Harrell, H. \& Reddy, S. (2008) Factors associated with medical students' career choices regarding internal medicine, JAMA, 300,10, pp.1154-1164.

Howe, A. \& Ives, G. (2001) Does communitybased experience alter career preference? New evidence from a prospective longitudinal cohort study of undergraduate medical students, Medical Education, 35, 4, pp.391397.

Karalliedde, L.D., Senanayake, N. \& Aluwihare, A.P.R. (1986) Career preferences of the 1984 medical graduates of Sri Lanka, Medical Education, 20, 1, pp.64-68.
Mendis, L., Goonaratna, C., Abeygunasekera, A. \& Abeykoon, P. (2006) Balancing the demand and supply of doctors in Sri Lanka. In: proceedings of the WHO / SLMA Symposium. Colombo: WHO / SLMA.

Morrison, J.M. \& Murray, T.S. (1996) Career preferences of medical students: influence of a new four-week attachment in general practice, British Journal of General Practice, 46,413, pp.721-725. 